\title{
Properties of Gold-Nickel Alloy Brazed Joints in High Temperature Materials
}

\author{
Professor Jakob Colbus \\ University of Saarland, Saarbrücken, West Germany
}

\section{and Karl Friedrich Zimmermann}

Degussa, Wolfgang, West Germany

The usefulness of gold-nickel alloys as brazing media in the aeroengine, electronic, nuclear power and spacecraft industries is illustrated by data on the corrosion and oxidation resistance of joints made with these alloys in various heat-resistant materials and on their resistance to fracture under the influence of static, dynamic and impact loads in tests at subzero, normal and elevated temperatures.

Gold solders have been in use for many years, especially in the jewellery trade and in dentistry. The solders used in the fabrication of jewellery contain silver, copper, cadmium, and zinc, which are added to ensure that the colour and the gold content of a given solder matches the corresponding characteristics of the soldered article. The solders used in dental practice often contain other precious metals such as iridium, palladium, and platinum introduced to increase their corrosion resistance, the most important property of solders of this kind. In both these applications the soldering is done in air with the aid of a gas torch and a suitable flux.

In recent years gold alloys have found new applications as joining media for high temperature service in the electronic, spacecraft and nuclear technologies. Alloys used in these applications must meet certain special requirements with regard to their ability to make joints which can work satisfactorily in vacuum and which are both heat- and corrosion-resistant; they must also be suitable for use with such joining methods as brazing in vacuum or in a protective atmosphere. Gold brazing alloys of this kind must therefore be free from volatile constituents such as cadmium and zinc; metals used as the alloying additions include copper, silver, palladium, and, especially, nickel.

Among many possible gold-base alloy systems there is only one which meets all the following requirements of a high-temperature brazing alloy:

Suitability for use in vacuum or in a protective atmosphere (i.e. freedom from constituents that are volatile and have a high affinity for oxygen);

Good wettability on heat-resistant materials and freedom from a tendency to excessive alloying so as to permit the brazing of thin-walled parts;
Brazing temperature in the range 900 to $1000^{\circ} \mathrm{C}$.

Ability to make joints that retain their strength and ductility at elevated temperatures.

Good resistance to oxidation and corrosion.

All these requirements can be satisfied by several alloys in the gold-nickel system, whose constitutional diagram is shown in Figure 1. The 18 per cent nickel-gold alloy is the most suitable one to serve as a brazing medium. Its melting point of $950^{\circ} \mathrm{C}$ is the

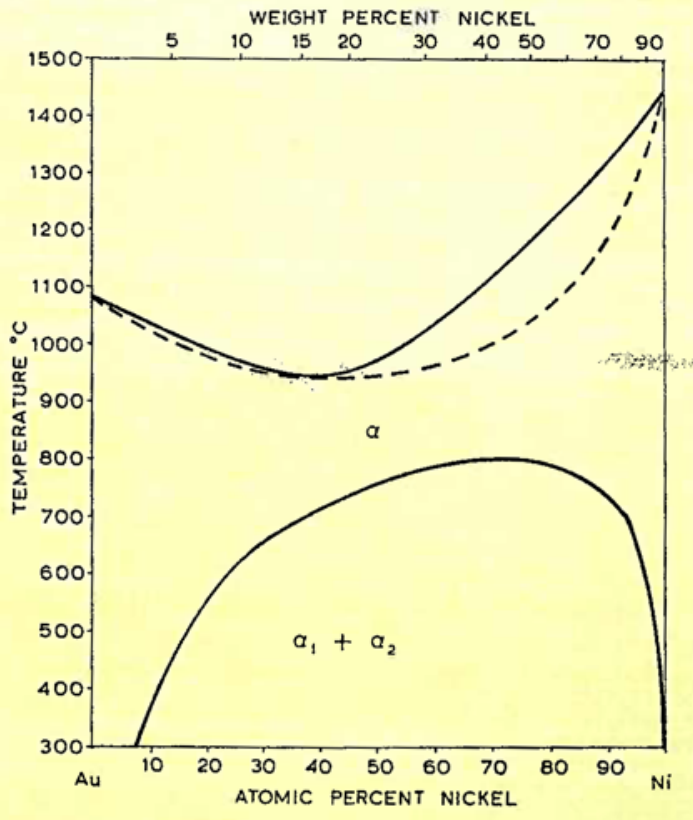

Fig. 1 The constitutional diagram of the gold-nickel system. The alloy containing 18 per cent of nickel is most generally used in brazing on account of its low melting point and good flowing characteristics 
Parts of the pipeline supplying oil to the bearings of a Pratt and Whitney aireraft engine. These are made from a stabilised nickel-chromium steel and were furnace brazed in vacuum with gold-nickel alloy pre-formed rings at a temperature of $1040^{\circ} \mathrm{C}$. All the brazed joints in this jet engine must withstand high pressure and vibration at a working temperature of $400^{\circ} \mathrm{C}$

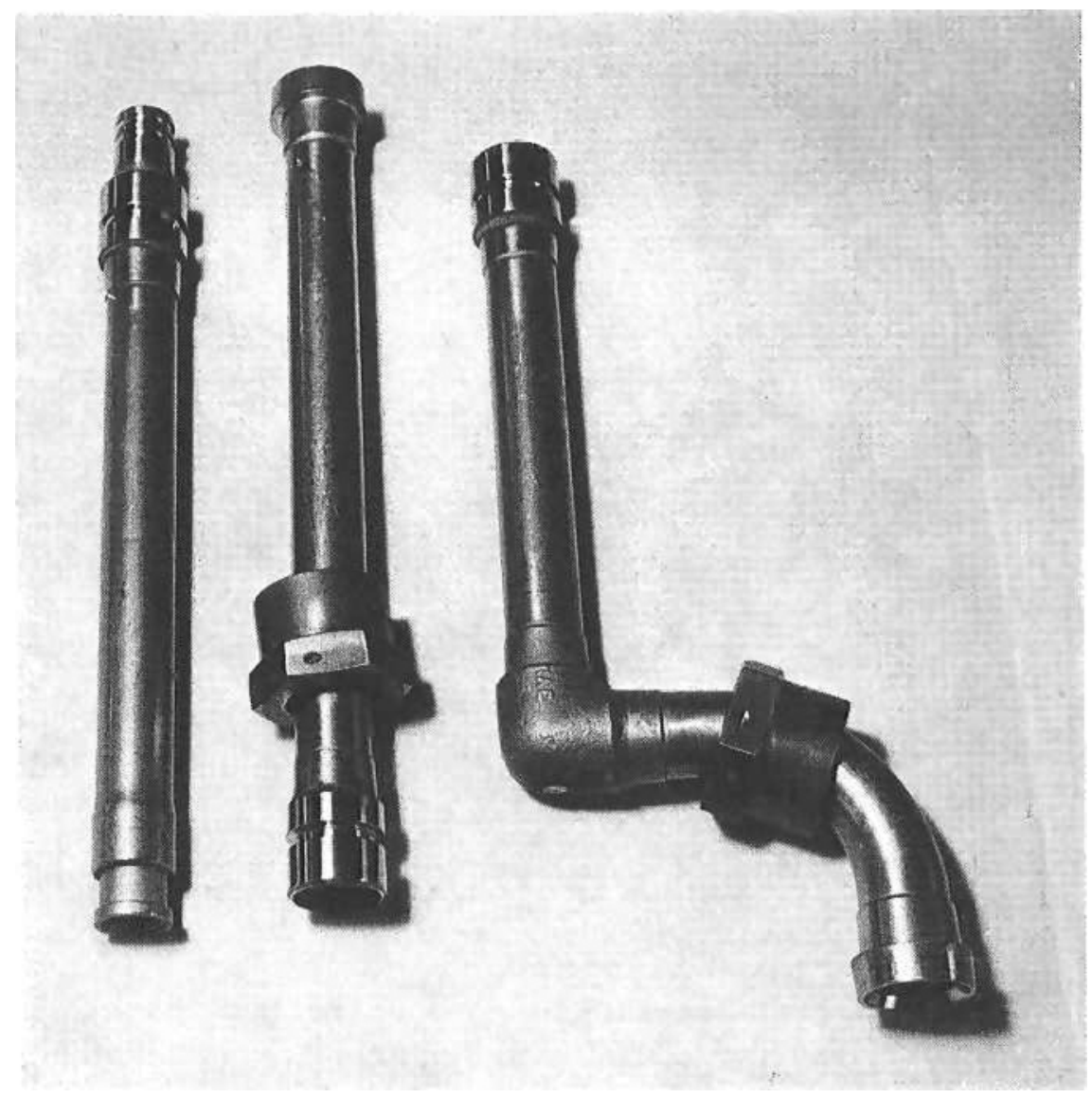

lowest one in the gold-nickel system and it has no melting range. Its melting characteristics resemble, therefore, those of a single metal; it does not liquate when melted, and it solidifies at a single temperature when cooled from its liquid state. Since gold and nickel form a continuous series of solid solutions at elevated temperatures, gold-nickel alloys solidify as a single-phase. Below $800^{\circ} \mathrm{C}$ there is a miscibility gap in the gold-nickel system so that gold-nickel alloys that are slowly cooled or subjected to a long heat treatment at a suitable temperature decompose into two facecentred cubic solid solutions (gold rich $\alpha_{1}$-phase

Table I

Composition of Parent Materials Used for Brazed Test Pieces

\begin{tabular}{|c|c|c|c|c|c|c|c|c|c|c|}
\hline \multirow{2}{*}{ Description } & \multicolumn{10}{|c|}{ Chemical Composition in Weight per cent } \\
\hline & C & $\mathrm{Fe}$ & $\mathrm{Cr}$ & $\mathrm{Ni}$ & Co & Mo & $\mathrm{Ti}$ & Al & $\mathrm{Nb} / \mathrm{Ta}$ & Other \\
\hline $\begin{array}{l}\text { Ni Cr } 20 \mathrm{Ti} \mathrm{Al} \\
\quad(\text { Nimonic } 80 \mathrm{~A})\end{array}$ & 0.06 & $<5.0$ & 20.0 & Balance & - & - & 2.4 & 1.4 & - & - \\
\hline X $12 \mathrm{Cr}$ Co Ni 2120 & 0.1 & Balance & 21 & 20 & 20 & 3.0 & - & - & 1.00 & $\begin{array}{l}2.5 \mathrm{~W} \\
0.15 \mathrm{~N}_{2}\end{array}$ \\
\hline X $8 \mathrm{Cr}$ Co Ni Mo 106 & 0.08 & Balance & 10.5 & 0.7 & 6.5 & 0.8 & - & - & 0.25 & $0.35 \mathrm{~V}$ \\
\hline $\begin{array}{l}\text { X } 8 \mathrm{Ni} \mathrm{Cr} \mathrm{Al} \mathrm{Ti} \\
\text { Mo } 7020\end{array}$ & 0.06 & 5 & 20 & Balance & - & 4.5 & 2.4 & 1.4 & - & - \\
\hline $\begin{array}{l}\mathrm{Ni} \mathrm{Cr} 20 \text { Co } 18 \mathrm{Ti} \\
\text { (Nimonic 90) }\end{array}$ & 0.06 & 5 & 20 & Balance & 18 & - & 2.5 & 1.5 & - & - \\
\hline X $10 \mathrm{Cr} \mathrm{Ni} \mathrm{Nb} 189$ & 0.068 & Balance & 17.1 & 10.4 & - & 0.54 & - & 0.07 & 0.73 & $\begin{array}{l}0.55 \mathrm{Si} \\
1.06 \mathrm{Mn}\end{array}$ \\
\hline
\end{tabular}


and nickel-rich $\alpha_{2}$-phase). Although the equilibrium is not as a rule reached in joints brazed with the 18 per cent nickel-gold brazing alloy when they are cooled at relatively fast rates in air or in a protective atmosphere, the decomposition of the homogeneous solid solution in these circumstances does occur to a certain extent; this has been proved by metallographic examination and electron microprobe analysis $(1,2)$.

The gold-nickel alloy in question has excellent wetting and capillary flow characteristics. Its other important advantage is that its degree of interalloying with heat-resistant steels and chromium- and cobaltbearing nickel alloys is extremely low; this has been verified in many industrial applications. Compared with standard brazing alloys that have similar melting points (such as brass, nickel-silver, or copper-manganese-cobalt alloys), it has the advantage of freedom from volatile constituents and a much greater resistance to heat and oxidation.

Unlike the well-known nickel-base high melting brazing alloys containing such alloying additions as chromium, boron, silicon, or phosphorus, most of which are brittle and, therefore, available only in powder form, the gold-nickel alloy has good workability and can be produced in the form of wire, foil and shaped pre-forms; it also makes more ductile joints.

\section{Mechanical Properties of Joints Brazed with Gold-Nickel Alloys}

In this article the results of various mechanical tests carried out on specimens brazed with the goldnickel alloy are discussed; these included short and long time tests under static loads at both room and elevated temperatures, fatigue tests, and impact tests. The composition of the parent materials (mainly cobalt-bearing austenitic steels and cobalt-free nickel-chromium alloys with low iron contents) used in the preparation of brazed test pieces is shown in Table I. All these materials have a high room
Table II

Tensile Strength of Several Parent Materials and Joints Brazed in These Materials with a Gold-Nickel Alloy

\begin{tabular}{c|c|c}
\hline Parent material & $\begin{array}{c}\text { Tensile Strength, daN } / \mathrm{mm}^{2} \\
\text { of the brazed } \\
\text { joint }\end{array}$ & $\begin{array}{c}\text { of the parent } \\
\text { material }\end{array}$ \\
\hline $\begin{array}{c}\text { Ni Cr 20 Ti Al } \\
(\text { Nimonic 80 A) }\end{array}$ & 75 & 120 \\
\hline $\begin{array}{l}\text { X Cr Co Ni Mo } \\
106\end{array}$ & 130 & 130 \\
\hline$\times 12 \mathrm{Cr}$ Co Ni & 75 & 80 \\
2120 & &
\end{tabular}

temperature strength, excellent resistance to heat and oxidation, and good thermal stability.

\section{Tensile Strength at Room Temperature}

Cylindrical specimens $10 \mathrm{~mm}$ diameter (with a joint clearance of about $0.06 \mathrm{~mm}$ ) induction-brazed in a vacuum of $2 \times 10^{-5}$ torr were used in the tensile tests. Some specimens were tested in the as-brazed condition and some after a post-brazing heat treatment of up to 1000 hours at $800^{\circ} \mathrm{C} \mathrm{(7)}$.

The results of tensile tests on untreated brazed specimens are reproduced in Table II which shows also the corresponding data for the parent materials. It will be seen that very high U.T.S. values were recorded for these specimens; in one case the joint strength was equal to that of the parent material.

The results of tensile tests on specimens heattreated after brazing are shown in Figure 2; in this case the 20 per cent CrNiTiAl alloy was used as the parent material. It was found that the room-temperature strength of these specimens depended to a large extent on the duration of the annealing treatment at $800^{\circ} \mathrm{C}$; after a 1000 hour anneal the initial tensile strength of $80 \mathrm{daN} / \mathrm{mm}^{2}$ was reduced to $60 \mathrm{daN} / \mathrm{mm}^{2}$.

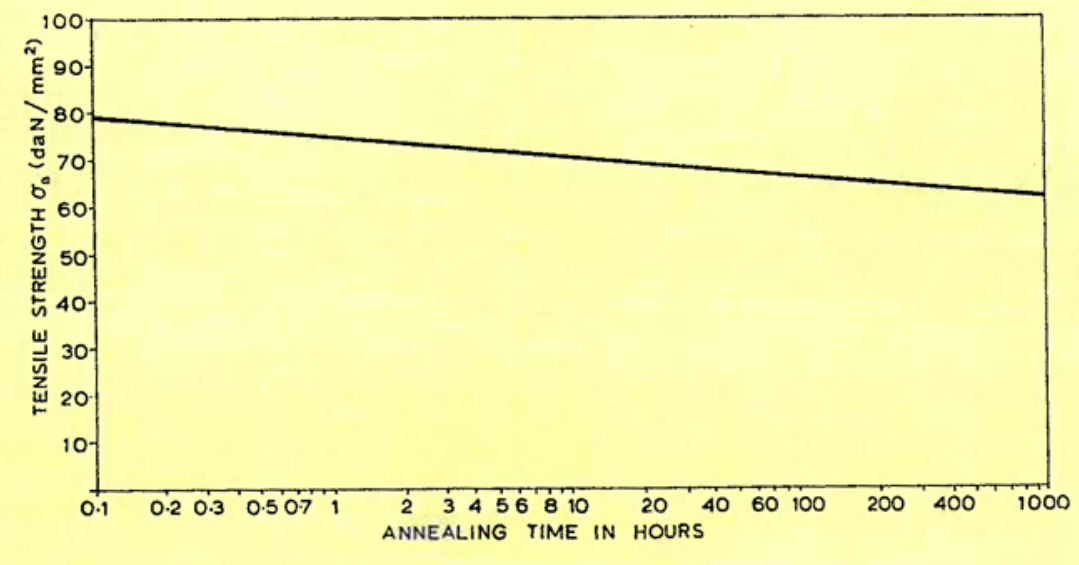

Fig. 2 Room-temperature tensile strength of joints brazed with a gold-nickel alloy in a heat-resistant material NiCr20TiAl plotted against annealing time at $800^{\circ} \mathrm{C}$ 
Fig. 3 Results of electron microprobe analysis of the transition zone between a gold-nickel brazing alloy and a parent metal (10CrNiNb189) presented as line profiles for $\mathrm{Au}, \mathrm{Cr}, \mathrm{Fe}$ and $\mathrm{Ni}$. They show that gold diffuses into the parent metal while iron and chromium diffuse into the brazing alloy

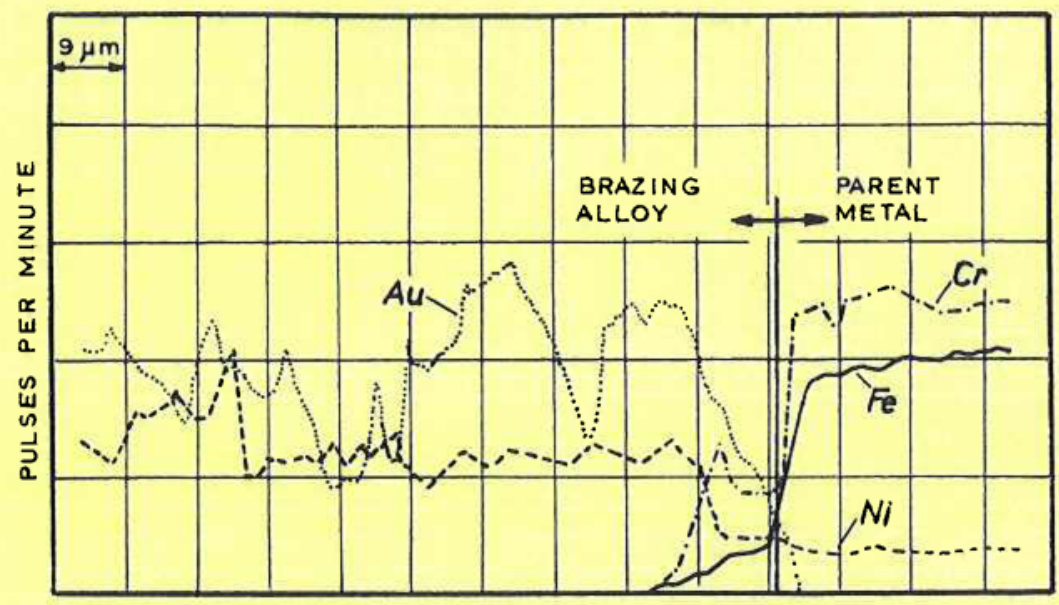

This effect was due to diffusion phenomena taking place both within the braze and between the braze and the parent material.

As shown by electron microprobe investigations $(2,7)$, the diffusion of gold into a nickel-bearing parent material, and of iron and chromium from the parent material into the brazing alloy, may take place even during the brazing operation. This effect is illustrated in Figure 3, which shows the results of electron microprobe analysis of the transition zone between a gold-nickel brazing alloy and the $\mathrm{X} 10 \mathrm{CrNiNb} 189$ parent material.

\section{Tensile Strength at Elevated Temperatures}

Figure 4 shows the temperature dependence of the tensile strength of joints brazed with a gold-nickel alloy in the 20 per cent CrNiTiAl parent material.

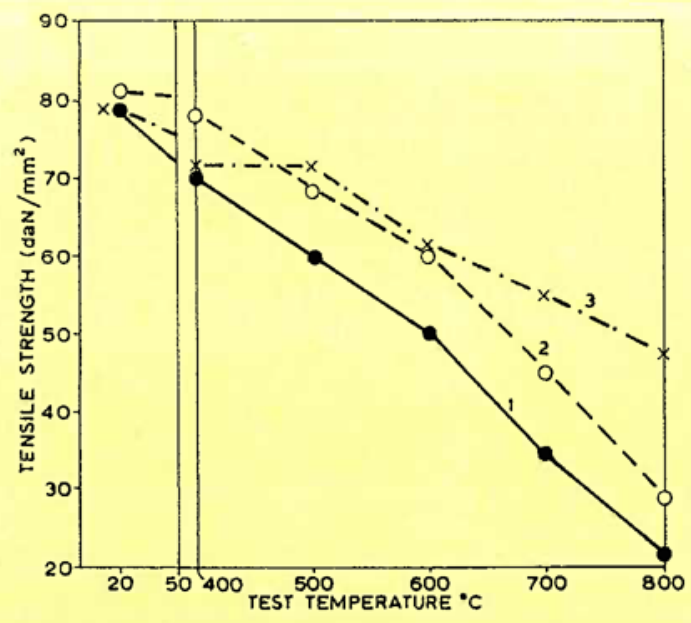

Fig. 4 Temperature dependence of the tensile strength of joints brazed with a gold-nickel alloy in NiCr20TiAl plotted for specimens given a heat treatment ( 16 hours at $710^{\circ} \mathrm{C}$ followed by air cooling) before (Graph 3) or after (Graphs 1, 2) brazing
It will be seen that this relationship depends on the parent material and the brazing method used. Graphs 1 and 2 in Figure 4 relate to specimens which were given a post-brazing treatment ( 16 hours at $710^{\circ} \mathrm{C}$ followed by cooling in air) to age-harden the parent material. The parent metal used in the preparation of specimens whose high-temperature properties are illustrated by Graph 3 in Figure 4 had been given the same treatment before brazing.

Graph 1 relates to specimens $5 \mathrm{~mm}$ diameter (with a joint clearance of $0.1 \mathrm{~mm}$ ) torch-brazed in air under a flux cover. The fact that the strength of these specimens was lower than that recorded (and plotted as graph 3) for other similarly heat-treated specimens is attributable to the smaller joint clearance and fluxless brazing in vacuum used in the latter case.

A sharp decrease in the joint strength was observed at $400^{\circ} \mathrm{C}$. At temperatures above $600^{\circ} \mathrm{C}$ the high-temperature strength of joints brazed in the parent material heat-treated before brazing (Graph 3) was higher than that of specimens that had been given a post-brazing treatment (Graphs 1 and 2).

\section{Creep Properties}

Data on creep properties of specimens brazed in the $\mathrm{NiCr} 20 \mathrm{TiAl}$ parent material and tested at 500 and $600^{\circ} \mathrm{C}$ are reproduced in Figure 5. It will be seen that at $600^{\circ} \mathrm{C}$ the breaking stress continuously decreases with increasing time under load and becomes negligibly small for time-to-rupture values exceeding 500 hours.

\section{Fatigue Strength at Room and Elevated Temperatures}

The fatigue properties of brazed joints were investigated by Lange ( 7 ) on specimens similar to those used in the tensile tests. The fatigue tests were carried out at room temperature and at $500^{\circ} \mathrm{C}$, both annealed and unannealed specimens being used in 


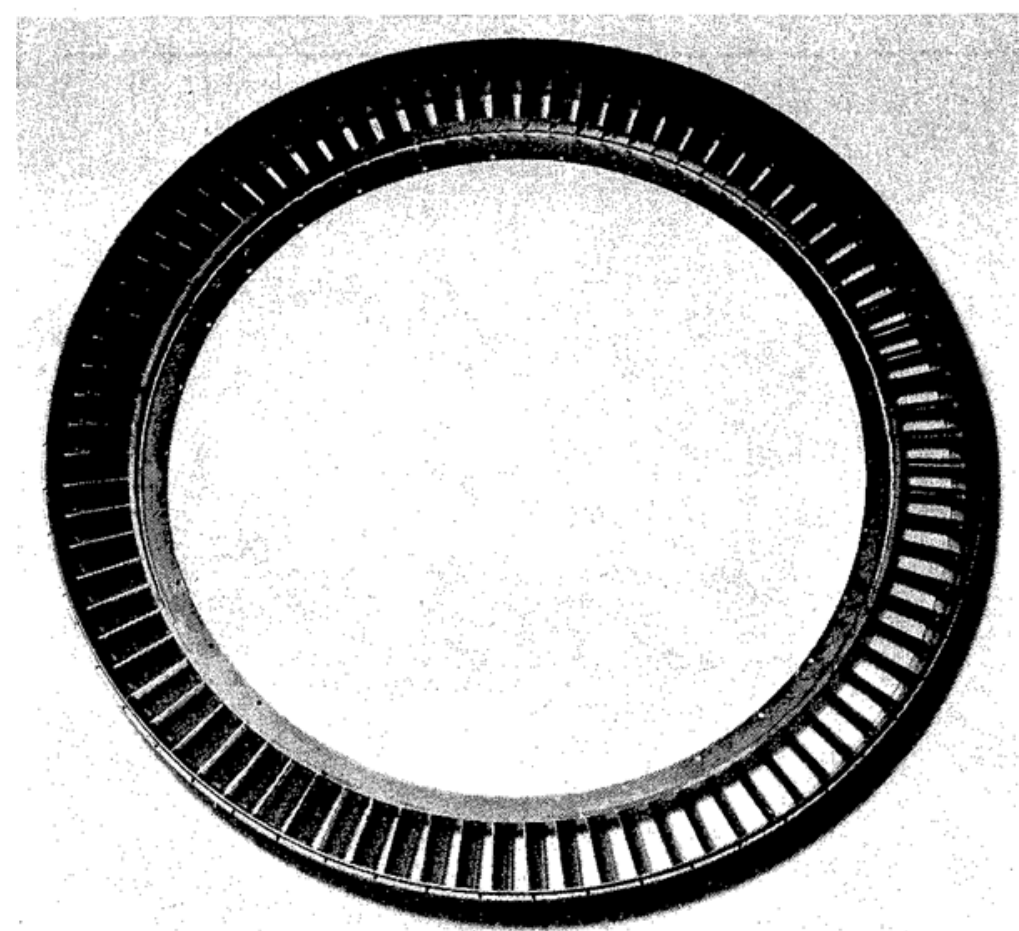

The guide blades of a 15-stage compressor in a Pratt and Whitney jet engine. In this case the blades, in a chrominm-nickel steel, are joined to the rim with a gold-nickel brazing alloy in the form of powder mixed with a cellulose binder. The parts were furnace brazed in vacuum at $1040^{\circ} \mathrm{C}$ with a joint clearance of 0.05 to $0.1 \mathrm{~mm}$.

room-temperature tests. The specimens were fatigued in tension, the applied stress varying between zero and its maximum value; the stress cycle frequency was $30 \mathrm{~Hz}$.

Test results reproduced in Figure 6 show that the fatigue strength of specimens tested at room temperature was on average about $10 \mathrm{daN} / \mathrm{mm}^{2}$ higher than that recorded for the test temperature of $500^{\circ} \mathrm{C}$. It

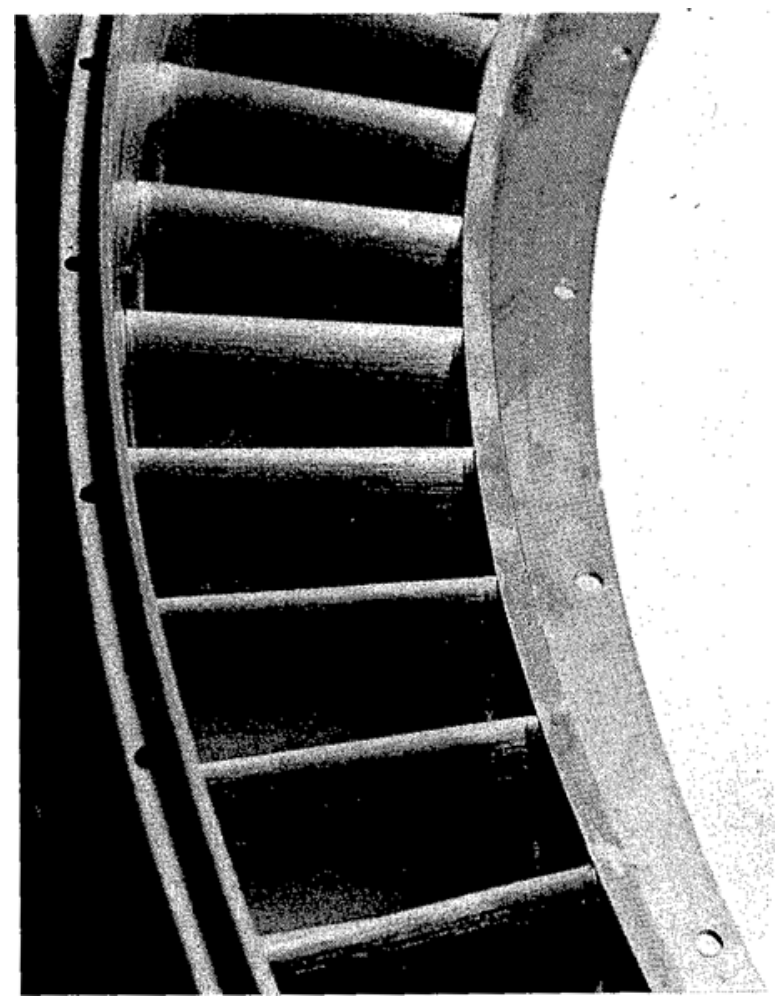

was found also that the fatigue strength of brazed joints depends to a large extent on the roughness of surfaces brazed. The endurance of specimens with finely-ground joint surfaces (roughness height $=0.3$ $\mu \mathrm{m}$ ) was half an order of magnitude lower than that of specimens with turned joint surfaces (roughness height $=8 \mu \mathrm{m}$ ).

Test results shown in Figure 7 relate to untreated specimens and to specimens that had been given an annealing treatment ( 100 hours at $800^{\circ} \mathrm{C}$ ) after brazing.

It will be seen that in the low-endurance range the fatigue strength of heat-treated brazed specimens was higher than that of unannealed test pieces. According to Lange this difference is attributable to a more uniform distribution of structural constituents in the joint region of heat-treated specimens.

In all the fatigue specimens tested the brazed foint proved to be the weakest region. Metallographic examination revealed that voids, shrinkage porosity and unwetted areas (present even in vacuumbrazed specimens) were usually the cause of the fatigue failure.

\section{Impact Bending Strength}

Impact bending tests (at room temperature and at $-196^{\circ} \mathrm{C}$ ) on brazed X10CrNiTi189 test pieces were carried out by Colbus (10). The square-section test

The gold-nickel brazed joints in the compreseor blades shown above can be clearly seen in this enlarged view 


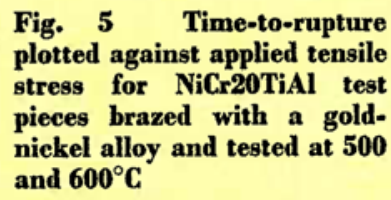

pieces measuring $55 \times 10 \times 10 \mathrm{~mm}$ had no artificial stress raisers, the brazing alloy layer in the middle of the test piece serving as a "notch". The results obtained for test pieces with joint clearances of $0.1,0.2$ and $0.3 \mathrm{~mm}$ tested on a $30 \mathrm{kgm}$ Charpy pendulum impact testing machine are reproduced in Table III. They show that the brazed joints in question have a very high ductility at both room and subzero temperatures, although their impact strength at $-196^{\circ} \mathrm{C}$ is somewhat reduced due to a decrease in the ductility of the brazing alloy.

The results of impact tests obtained by Chang (11) for standard notched Charpy bar brazed specimens were cited in a paper by Sloboda (5). These tests were carried out at room temperature and at $650^{\circ} \mathrm{C}$; their results converted to Joule $/ \mathrm{cm}^{2}$ units are shown in Table IV. Not surprisingly, these impact strength values are lower than those recorded by Colbus because the geometrical stress-raiser (present in addition to the "notch" formed by the brazing alloy layer) produced in this case a state of bi-axial stress which decreases the resistance of the brazing alloy to fracture.

In every case higher impact strength values were
Fig. 6 Fatigue curves of NiCr20TiAl test pieces brazed with a gold-nickel alloy and tested at room temperature and $600^{\circ} \mathrm{C}$

Fig. 7 Fatigue curves of NiCr20TiAl test pieces brazed with a gold-nickel alloy and tested at room temperature. Test pieces annealed for 100 hours at $800^{\circ} \mathrm{C}$ and unannealed
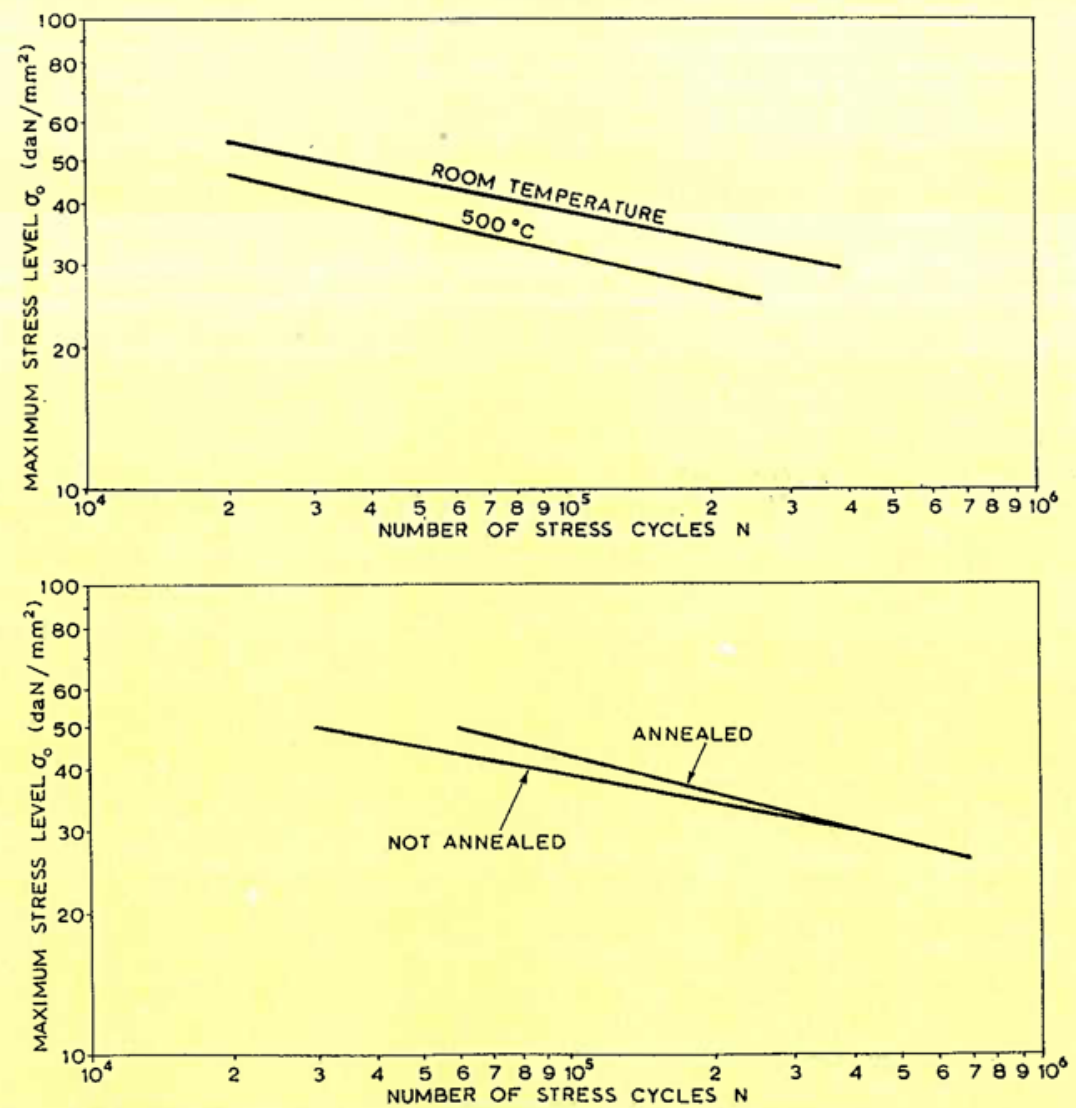
Table III

Impact Bending Strength of Joints Brazed with a Gold-Nickel Alloy in the Parent Material X10CrNiTil89

(Determined on test pieces measuring $55 \times 10 \times 10 \mathrm{~mm}$.)

\begin{tabular}{|c|c|c|}
\hline \multirow{2}{*}{$\begin{array}{c}\text { Joint } \\
\text { Clearance, } \\
\text { mm }\end{array}$} & \multicolumn{2}{|c|}{$\begin{array}{l}\text { Impact Bending Strength } \\
\left(\mathrm{J} / \mathrm{cm}^{2}\right) \text { at }\end{array}$} \\
\hline & $\begin{array}{c}\text { Room } \\
\text { Temperature }\end{array}$ & $-196^{\circ} \mathrm{C}$ \\
\hline 0.1 & 66 & 48 \\
\hline 0.2 & $\begin{array}{c}\text { Specimen } \\
\text { unbroken; slip } \\
\text { lines formed }\end{array}$ & 50 \\
\hline 0.3 & 62 & 55 \\
\hline
\end{tabular}

recorded at $650^{\circ} \mathrm{C}$ than at room temperature. This is because of bi-axial stress relaxation and increased ductility of the brazing alloy at elevated temperatures.

\section{Diffusion between the Brazing Alloy and the Parent Material}

The fact that the joint strength is substantially increased by a post-brazing heat treatment necessitated further studies of the diffusion between the brazing alloy and the parent metal. The way in which gold and nickel on the one side and chromium and molybdenum on the other migrated across the original joint interface is illustrated by data in Figure 8 (2). The parent metal in this case was the alloy $\mathrm{X} 8 \mathrm{NiCr}$ AlTiMo7020, and the test piece was annealed after brazing for 1000 hours at $800^{\circ} \mathrm{C}$ and cooled in air. The chromium content in the parent metal portion of the diffusion zone was greatly reduced, the nickel and molybdenum contents being only slightly decreased. Large quantities of gold migrated from the brazing alloy into the diffusion zone and into the parent metal; gold could be detected at a distance of $80 \mu \mathrm{m}$ from the joint interface.

The micrograph in Figure 8 shows that the brazing alloy matrix constitutes a gold-rich $\alpha_{1}$ solid solution containing about 2.5 per cent chromium and 2 per cent molybdenum. Dispersed in the light-etching $\alpha_{1}$ matrix are dark-etching particles (of various shape and size) of a nickel-rich $\alpha_{2}$ solid solution which, in addition to gold and nickel, contain about 5 per cent chromium and 2.7 per cent molybdenum.

Coarsely-dispersed $\gamma$-phase $\left(\mathrm{Ni}_{3}(\mathrm{Al}, \mathrm{Ti})\right)$ particles can be seen in the unaffected part of the parent metal etched to reveal the presence of this phase which is absent in the diffusion zone obviously because this zone has been denuded of titanium and nickel as a result of their diffusion into the brazing alloy.

The hardness of the diffusion zone is only 235
Table IV

Impact Strength of Joints Brazed with a GoldNickel Alloy in Various Parent Materials Test Piece - Charpy notched bar

\begin{tabular}{|c|c|c|c|}
\hline $\begin{array}{l}\text { Parent } \\
\text { material }\end{array}$ & \begin{tabular}{|} 
Joint \\
Clearance, \\
$\mathrm{mm}$
\end{tabular} & $\begin{array}{c}\text { Test } \\
\text { tempera- } \\
\text { ture, } \\
{ }^{\circ} \mathrm{C}\end{array}$ & $\begin{array}{l}\text { Notch } \\
\text { impact } \\
\text { strength, } \\
\mathrm{J} / \mathrm{cm}^{2}\end{array}$ \\
\hline $\begin{array}{l}\text { (To DIN } \\
\text { Standard) }\end{array}$ & 0 & 20 & 15 \\
\hline X $8 \mathrm{Cr} \mathrm{Ni} 189$ & 0 & 650 & 19 \\
\hline $\begin{array}{l}\text { (To ASTM } \\
\text { standard) }\end{array}$ & 0.1 & 20 & 10 \\
\hline AISI 347 & 0.1 & 650 & 14 \\
\hline $\begin{array}{l}\text { (To DIN } \\
\text { standard) } \\
\text { X } 15 \mathrm{Cr} 13\end{array}$ & 0 & 20 & 2.2 \\
\hline $\begin{array}{l}\text { Precipitation } \\
\text { aged after } \\
\text { brazing }\end{array}$ & 0 & 650 & 14 \\
\hline $\begin{array}{l}\text { (To ASTM } \\
\text { standard) }\end{array}$ & 0.1 & 20 & 14 \\
\hline $\begin{array}{l}\text { Annealed after } \\
\text { brazing }\end{array}$ & 0.1 & 650 & 23 \\
\hline
\end{tabular}

$\mathrm{daN} / \mathrm{mm}^{2}$; this is less than the figures recorded for the brazing alloy $\left(260 \mathrm{daN} / \mathrm{mm}^{2}\right)$ and the parent material (330 daN $/ \mathrm{mm}^{2}$ ). Obviously, the diffusion zone is the weak spot in a brazed part.

Numerous photomicrographs and results of electron microprobe analysis found in the literature $(2,3)$ show that the diffusion phenomena described above take place in all brazed joints of this kind.

\section{Oxidation and Corrosion of Brazed Joints}

Although relatively thick surface oxide layers are formed on gold-nickel brazing alloy specimens held for a long time in air at $700^{\circ} \mathrm{C}$ or $800^{\circ} \mathrm{C}$, test pieces

Table V

Corrosion of Joints Brazed with a Gold-Nickel Alloy

\begin{tabular}{c|c}
\hline Test conditions & Test results \\
\hline $\begin{array}{l}100 \text { hours in a } \mathrm{NaF}-\mathrm{ZrF}_{4}-\mathrm{UF}_{4} \\
\text { mixture at } 815^{\circ} \mathrm{C}\end{array}$ & $\begin{array}{c}\text { Braze fillet } \\
\text { unaffected }\end{array}$ \\
\hline 100 hours in $\mathrm{NaOH}$ at $815^{\circ} \mathrm{C}$ & $\begin{array}{c}\text { Fillet attacked to } \\
\text { a depth of } \\
0.001 \text { inch }\end{array}$ \\
\hline 100 hours in $\mathrm{NaOH}$ at $595^{\circ} \mathrm{C}$ & No corrosion
\end{tabular}


brazed with alloys of this kind have been shown to have a high oxidation resistance. Thus, the results of an investigation in which brazed test pieces were held for 1000 hours in air at $800^{\circ} \mathrm{C}(12)$ showed that the oxidation depth did not exceed 0.026 $\mathrm{mm}$ for any of the brazing alloyparent metal combinations tested. Similar figures are cited in Sloboda's article (5) for brazed specimens tested under the same conditions. The difference between the oxidation resistance of gold-nickel alloys tested on their own and as joining media in brazed assemblies is obviously due to the fact that in the latter case the parent metal constituents, especially chromium, diffuse into the brazing alloy at temperatures between $700^{\circ}$ and $800^{\circ} \mathrm{C}$ and increase its resistance to oxidation.

With regard to the corrosion resistance of gold-nickel alloys, some data on their behaviour in fused $\mathrm{NaOH}$ and $\mathrm{NaF}-\mathrm{ZrF}_{4}-\mathrm{UF}_{4}$ mixtures used in nuclear reactor technology are reproduced, after Sloboda (5), in Table V.

\section{Applications}

Where a good performance in a brazed joint in conditions of high temperature or in a corrosive atmosphere - or in a combination of both is required, the data reviewed here on the properties of joints brazed with
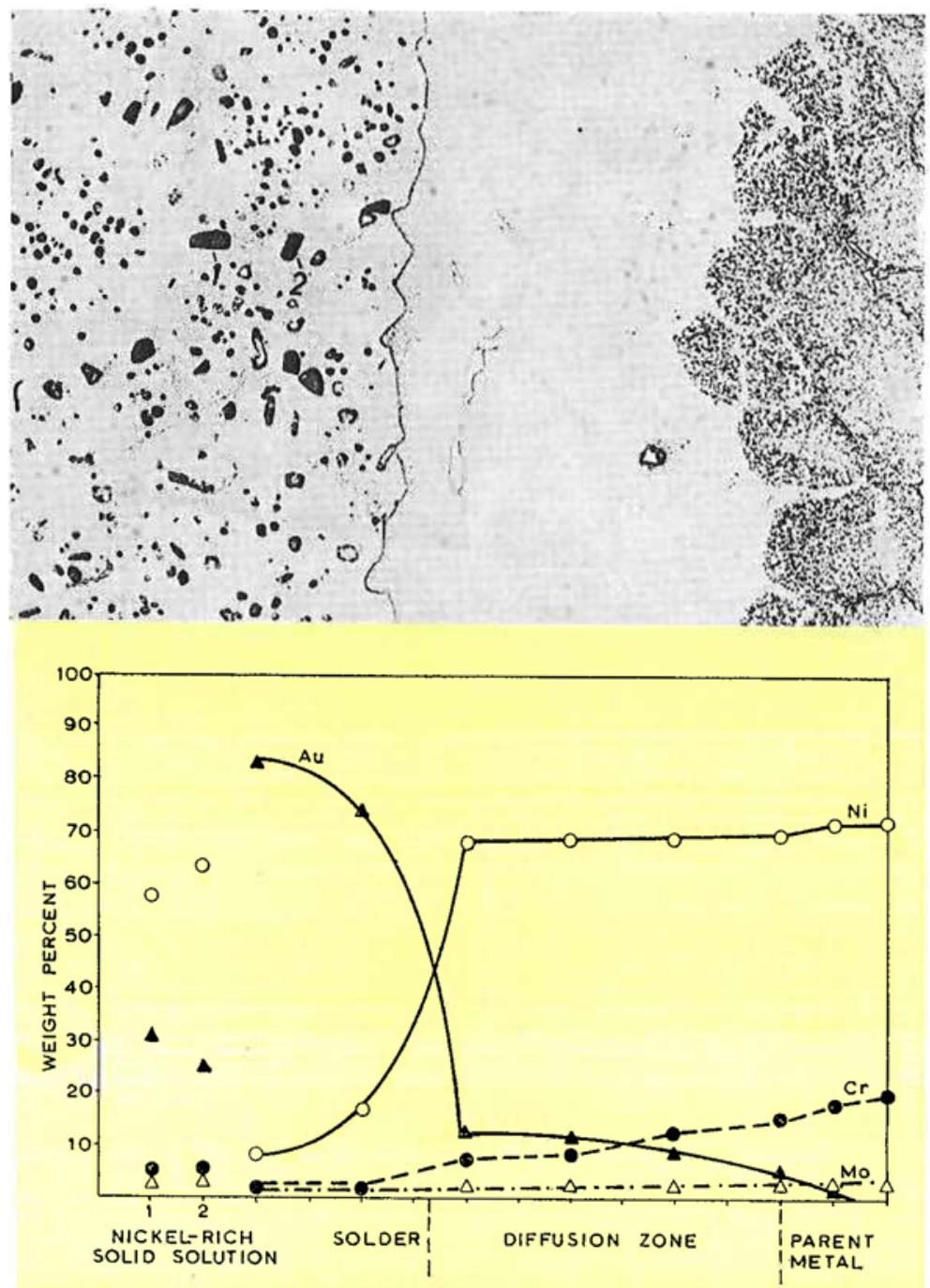

Fig. 8 Electron microprobe line profiles for $\mathrm{Au}, \mathrm{Ni}, \mathrm{Cr}$ and $\mathrm{Mo}$ and a micrograph $(\times 500)$ obtained for the transition zone between a goldnickel brazing alloy and a parent metal (X8NiCrAlTiMo7020) in a specimen annealed $\left(1000\right.$ hours at $800^{\circ} \mathrm{C}$ in air) after brazing a gold-nickel alloy clearly demonstrate the usefulness of this means of assembly. The applications illustrated are drawn only from aeroengine technology, but numerous other uses are being

established in the nuclear energy field, in the electronic industry and in the building of space vehicles, in a wide range of structural materials.

\section{References}

1 W. Hauch, Dissertation, Hanover, 1968

2 J. Colbus and A. Keller, Doctoral Thesis, Saarbrücken, 1968

3 J. Colbus and W. Hauch, "The Creep Behaviour of Joints made with High-Resistant Materials and Tested for Periods of up to 1000 hours at Temperatures of up to $800^{\circ} \mathrm{C}$," Metall, 1969, 23, (10), 994-1002

$4 \mathrm{H}$. Lange, "Mechanical Properties of Vacuum-Brazed Heat-Resistant Materials," Schweissen and Schneiden, 1971, 23, (1), 3-6

5 M. H. Sloboda, "Industrial Gold Brazing Alloys," Gold Bulletin, 1971, 4, (1), 2-8

$6 \mathrm{~J}$. Colbus, "Creep Strength and Oxidation Resistance of Joints Brazed in Heat-Resistant Materials Tested for up to 1000 hours at Temperatures between 300 and $700^{\circ} \mathrm{C}, "$ Metall, 1971, 25, (10), 1103-1109
$7 \mathrm{H}$. Lange, "The Use of High-Temperature Vacuum Brazing for Making Leak-Proof Joints in HeatResistant Materials," Metall, 1972, 26, (8), 814-820

$8 \mathrm{~J}$. Colbus and K. F. Zimmermann, "High-Temperature Properties of Brazing Alloys and Brazed Joints," Verbindungstechnik, 1973, (1)

$9 \mathrm{H}$. D. Steffens and H. Lange, "Fatigue Strength of Joints Brazed with High-Temperature Materials," Werkstofftechnik, 1972, 3, 296-301

$10 \mathrm{~J}$. Colbus, Unpublished test results

11 W. H. Chang, "Basic Characteristics of Some HeatResisting Brazing Filler Materials," Welding $\mathcal{F}_{\text {., 1956, }}$ 35, (9) 431 s-443s; "Further Evaluation of Ni-Cr-B and Au-18Ni Brazing Alloys," Ibid., 1958, 37, (12), 535s$542 \mathrm{~s}$

12 J. Colbus and P. Thiel, Thesis, Saarbrücken, 1969 